\title{
Chapter 24 \\ Farmer-To-Farmer Extension: A Low-Cost Approach for Promoting Climate-Smart Agriculture
}

\author{
Steven Franzel, Evelyne Kiptot, and Ann Degrande
}

\subsection{Introduction}

The rise in importance of climate-smart agriculture (CSA) has been accompanied by increased concern over how CSA practices can be scaled up to reach millions of smallholder farmers. While climate-smart agricultural practices-like conventional ones-are sometimes complex and knowledge-intensive, public investment in extension services has been declining in many countries (Harvey et al. 2014). This situation makes it increasingly difficult for farmers to access the CSA information they need. McCarthy et al. (2011) cite the high cost of accessing information and the key role that extension can play in reducing the cost and the risks of adopting CSA practices. Lipper et al. (2014) claim that public financial support is needed to promote CSA through extension services and other types of information dissemination.

In the face of increased demand for agricultural information and the reduced capacity of extension systems, many extension providers have been using farmerto-farmer extension (F2FE), which is defined as the provision of training by farmers to farmers, often through the creation of a structure of farmer-trainers (Scarbourough 1997). Surveys reveal that most farmers rely on other farmers as their primary source of information about new technologies. The F2FE approach therefore can be viewed as an extension of farmers' existing practices. We use "farmer-trainer" as a generic term, even though we recognize that different names (e.g., lead farmer, farmer-promoter, community knowledge worker) may imply somewhat different roles.

\footnotetext{
S. Franzel $(\bowtie) \cdot$ E. Kiptot

World Agroforestry Centre (ICRAF), Nairobi, Kenya

e-mail: s.franzel@cgiar.org
}

\author{
A. Degrande \\ World Agroforestry Centre (ICRAF), Yaounde, Cameroon \\ e-mail: a.degrande@cgiar.org
}


F2FE programs have a long history, having been used in the Philippines since the 1950s and in Central America since the 1970s (Selener et al. 1997). They have grown tremendously in Africa in recent years (Simpson et al. 2015) and are now quite common, with $78 \%$ of a sample of 37 development organizations using the approach in Malawi (Masangano and Mthinda 2012) and 33\% using it across seven regions of Cameroon (Tsafack et al. 2014). At least two public extension systemsthose of the Rwanda Agricultural Board and the Ministry of Agriculture in Malawieach work with over 12,000 farmer-trainers.

The objective of this paper is to assess the potential of F2FE to promote CSA, based on experiences in Cameroon, Kenya and Malawi. Specifically, we assess the approach based on the following four criteria:

- Extension program managers' perceptions of the approach

- The effectiveness of the approach as a means for training farmers

- The efficiency of the approach, as judged by comparing its costs per trained farmer with the costs of an approach in which extension agents train groups of farmers

- The potential of the approach for improving the proportion of female extension providers

First, we describe the methods used in the study and the main features of the F2FE approach as it is applied in the three countries. Next, we examine each of the four criteria in turn. Finally, we focus on the implications of the results for using the F2FE approach to promote CSA, especially those CSA practices that are complex and knowledge-intensive.

\subsection{Methods}

This study relied on semi-structured surveys of extension program managers to assess 80 development organizations' experiences with F2FE in the following countries:

- Cameroon (25 organizations operating in the 5 southernmost of the country's 8 regions) (Tsafack et al. 2014)

- Kenya (30 organizations in Rift Valley, Western and Nyanza provinces) (Franzel et al. 2014)

- Malawi (25 organizations across all three of the country's administrative regions) (Kundhlande et al. 2014)

The organizations included international non-governmental organizations (NGOs) (39\%), national or local NGOs (35\%), government agencies (14\%), producer organizations (10\%) and private companies (2\%). Most of the sampled extension program managers were using not only F2FE but also three or four other 
approaches (such as farmer field schools, training groups, exchange visits and field days). Given this diversity of approaches, the managers were not likely to be biased in favor of F2FE, as they might have been had they been using F2FE alone. Sampling was done using the snowball sampling method, in which respondents directed interviewers to other potential respondents (Goodman 1961). This method was used because no lists of development organizations using the F2FE approach were available.

In Cameroon and Malawi, interviews were also conducted with 160 and 203 randomly selected farmer-trainers, respectively, who were working with the organizations visited (Tsafack et al. 2015; Khaila 2015). No such survey was conducted in Kenya because of the availability of a data set from interviews with 99 randomly selected farmer-trainers working with a dairy project (Kiptot and Franzel 2012). In Kenya, a survey also was conducted of 113 randomly selected trainees (farmers trained by farmer-trainers) to confirm that they had indeed been trained and to determine their level of knowledge about the improved practices and whether they were using them (Kiptot et al. 2013).

\subsubsection{Main Features of the Approach}

The organizations surveyed used farmer-trainers for a wide variety of enterprises and initiatives, including livestock, crops, agroforestry, nutrition and sustainable land management. Proportions of organizations promoting CSA (or some component of it, such as conservation agriculture) ranged from $4 \%$ in Cameroon to $23 \%$ in Kenya and $40 \%$ in Malawi. The most common terms for those doing the training were lead farmers, farmer-trainers, contact farmers and community facilitators. The uptake of the approach appears to be fairly recent: In all three of the countries, over half of the organizations reported having adopted it over the 7 years prior to 2014 .

The trainers' main roles were to train farmers, to follow up with those farmers, and to mobilize them for meetings and training events. Most trainers (over $84 \%$ in all three countries) received an initial training (often 1 week in length), and nearly half received additional training after they had served for some time. Many hosted a demonstration plot. Over $72 \%$ of farmer-trainers in each country received training materials such as leaflets and brochures.

In most cases their key responsibility was to train other members of their own farmer groups, although sometimes they worked with neighboring groups as well. In only a few cases did they serve villages. In 25 of the organizations, the trainers received no compensation; in 43 they were compensated for some expenses such as communication and travel to meetings; and in 12 they received salaries or periodic allowances. There was little variation among countries in the proportions of farmertrainers compensated in these various ways. 


\subsubsection{Extension Program Managers'Perceptions of the Approach}

In the surveys, the managers of extension program expressed widespread satisfaction with F2FE as a means to promote the adoption of innovations (Simpson et al. 2015). Median scores across the three countries on the overall effectiveness of the approach ranged from 7.5 to 8 out of 10 in each of the 3 countries, with a score of 1 being not effective and 10 being extremely effective. Over $70 \%$ of respondents in each country gave the approach a score of 7 or 8 . The main benefits of the F2FE approach, as perceived by over $60 \%$ of organizations using it, was that it boosted their ability to cover large areas and reach large numbers of farmers (Fig. 24.1). Many also cited the enhanced sustainability of extension efforts, because they believed that farmer-trainers would continue their training work even after the projects ended. In fact, there is considerable evidence that volunteer trainers continue working effectively after the projects supporting them come to an end-either because the government takes over support (Kiptot et al. 2016); because the trainers are accountable to local community structures (Lukuyu et al. 2012); or because producer organizations support them (Karanja et al. 2017). Many managers also felt that the approach helped increase adoption rates because farmers preferred to learn novel practices from their colleagues rather than from extension staff.

Organizations reported three main problems in implementing F2FE programs (Fig. 24.2). First, as reported by over $40 \%$ of organizations in Cameroon and over $20 \%$ in Kenya and Malawi, farmers sometimes had unreasonably high expectations in terms of financial and non-financial benefits, despite organizations' attempts to reduce such expectations. Unmet expectations could be a cause of high dropout

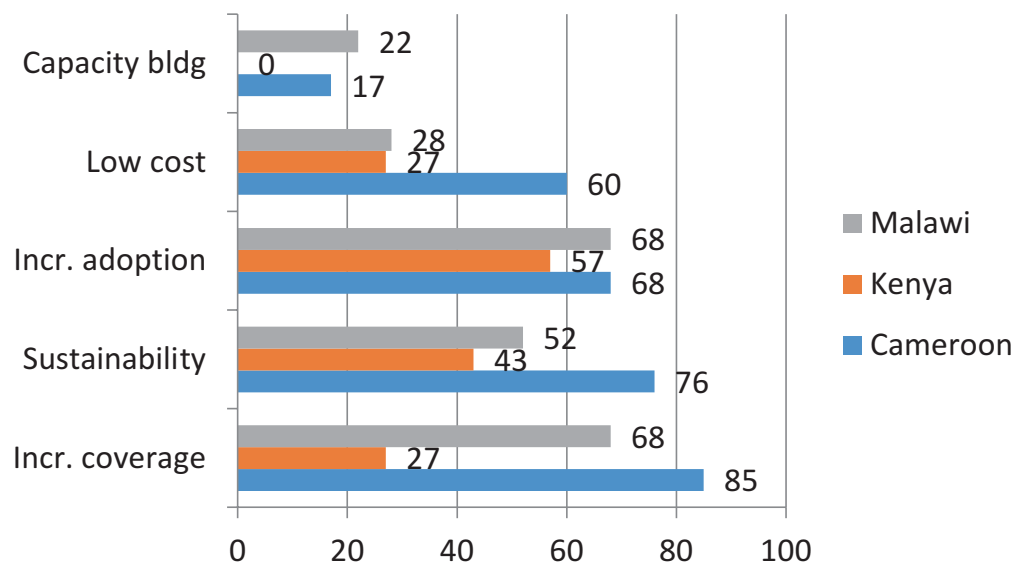

Fig. 24.1 Organizations' views of the main benefits of farmer-to-farmer extension programs (percent of organizations reporting) 


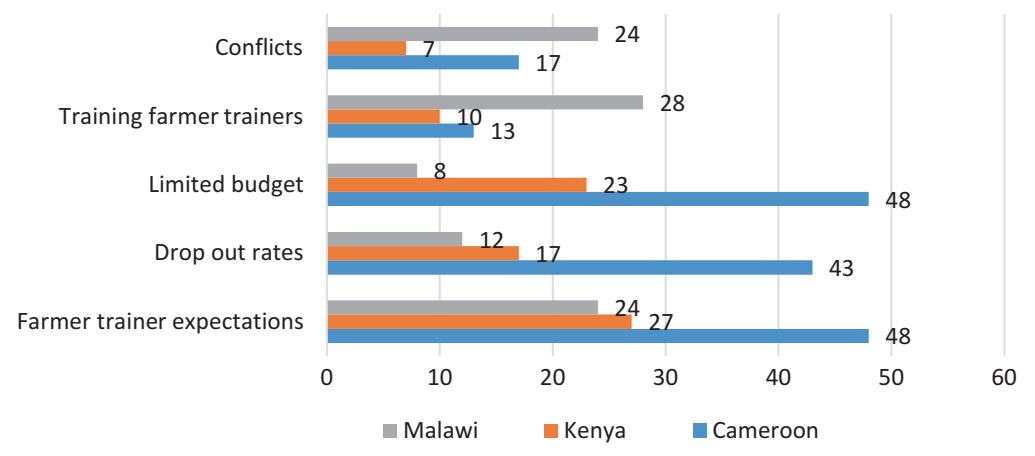

Fig. 24.2 Organizations' views of the main problems of farmer-to-farmer extension programs (percent of organizations reporting). Note: Conflicts refers to conflicts between organizations using the same volunteer farmers or problems arising when organizations compensate their farmertrainers differently or offer contradictory recommendations to farmers

rates, which were also reported as a problem. Limited budgets for supporting farmer-trainers also created challenges.

\subsubsection{Effectiveness of the Approach}

Overall findings on effectiveness were positive. In Kenya, farmer-trainers each reported training an average of 201 farmers (median: 37) over the month prior to the interview. In Cameroon the average was 58 (median: 17) over the previous year (Tsafack et al. 2015), and in Malawi the number was 61 (median: 25) over the previous year. In all three countries, averages were skewed upward because a few of the farmer-trainers hosted large numbers of trainees who had been brought in by NGOs or other extension providers. The median number of farmers trained by typical farmer-trainers (17-37) approximates the number of members in the groups to which the farmer-trainers belonged and to whom their training was targeted.

In Kenya, the effectiveness of farmer-trainers was corroborated by a survey of 113 randomly selected trainees, who were found to be knowledgeable about the innovations on which they had received training, and most of whom were testing some of the new practices they had learned (Kiptot et al. 2013).

\subsubsection{Efficiency of the Approach}

An extension approach is deemed to be cost-efficient if the cost per farmer trained is lower than that of alternative approaches. Table 24.1 compares the cost efficiency of an F2FE program in Malawi with a conventional program in which extension 
Table 24.1 Comparison of cost efficiency of an F2FE program in Malawi with a conventional program in which extension staff members directly train farmer groups

\section{A. Cost of maintaining a front-line extension staff member (dollars/year)}

\begin{tabular}{l|l}
\hline Salary & 3600 \\
\hline Fringe benefits & 1200 \\
\hline Fuel & 200 \\
\hline Motorbike & $\begin{array}{l}1200 \text { cost of 3000, depreciated over 3 years, plus \$200 maint/ } \\
\text { year }\end{array}$ \\
\hline $\begin{array}{l}\text { Other (comm., training } \\
\text { materials) }\end{array}$ & $240 \$ 20 /$ month \\
\hline Total & 6440 \\
\hline B. Cost of maintaining a farmer trainer (dollars/year) \\
\hline Demo plot inputs & 30 \\
\hline Bicycle & $\begin{array}{l}50(\text { cost of } 150 \text { depreciated over 3 years. No maintenance } \\
\text { provided }\end{array}$ \\
\hline Badge, t-shirt, cap, gum boots & 30 \\
\hline Training costs 2 days per year & $\begin{array}{l}150 \text { (residential training incl room }(\$ 30 * 2), \text { board }(\$ 20 * 2), \\
\text { transp. }(\$ 20)), \text { trainers }(\$ 10), \text { training materials }(\$ 20)\end{array}$ \\
\hline Total & 260
\end{tabular}

C. Model 1 extension worker trains 10 farmer groups

\begin{tabular}{l|l}
\hline $\begin{array}{l}\text { Each extension staff spent } \\
10 \text { days per month training }\end{array}$ & 10 days per month \\
\hline $\begin{array}{l}\text { Each trains } 10 \text { farmers }(1 \text { club) } \\
\text { per day of training }\end{array}$ & 10 farmers trained per day of training \\
\hline Farmers trained per month & 100 farmers trained per month \\
\hline Farmers trained per year & 100 Same farmer groups visited once per month \\
\hline Cost per farmer trained & 65 costs are cost of extension staff +2 demos \\
\hline
\end{tabular}

\section{Model 2. Farmer to farmer extension model}

\begin{tabular}{l|l}
\hline $\begin{array}{l}\text { Each extension staff spent } \\
10 \text { days per month training }\end{array}$ & 10 days per month \\
\hline $\begin{array}{l}\text { Each extension staff trains } 20 \\
\text { LFs per month }\end{array}$ & 20 lead farmers \\
\hline $\begin{array}{l}\text { Each lead farmer trains } 20 \\
\text { farmers }\end{array}$ & 20 farmers trained \\
\hline Total farmers trained per month & 400 farmers trained \\
\hline Cost per farmer trained & $\begin{array}{l}29.1 \text { Costs are cost of extension staff }+ \text { cost maintaining 20 } \\
\text { farmer trainers }\end{array}$ \\
\hline $\begin{array}{l}\text { E. Ratio of costs per farmer in } \\
\text { model 1 over model 2 }\end{array}$ & 2.2 \\
\hline
\end{tabular}

The cost of training extension staff in the two approaches, F2FE and the group training, are considered to be the same and are thus not included in the model

staff members directly train farmer groups. The data in the model are from interviews with extension staff. The cost of a front-line extension staff member-which is a cost in both models - is $\$ 6440$ per year, and the cost of a farmer-trainer is $\$ 260$ per year. In model 1 , the conventional approach, an extension worker trains 100 
farmers per year at a cost of $\$ 65$ per farmer. In model 2, an extension worker trains 20 farmer-trainers per year, each of whom trains 20 farmers, amounting to 400 farmers at a cost of \$29 per farmer. The cost per farmer trained in the F2FE model is thus 55\% lower than the cost in the conventional approach. If farmer-trainers trained only 9 farmers instead of 20 , the 2 models would have the same costs per farmer trained. The analysis omits some costs (e.g., training of extension staff and administrative costs) that are not likely to vary between the different approaches.

\subsubsection{The Approach's Potential for Increasing the Proportion of Female Extension Providers}

Gender imbalance in agricultural extension has been widely recognized as an important challenge (World Bank, FAO, IFAD 2009; GFRAS 2014). The problem is generally attributed to two key facts: women make up only a small proportion of extension staff, and female farmers have less access to extension services than do male farmers. The low proportion of female staff has been linked to the fact that relatively few women enroll in the agricultural extension departments of universities and training institutes or choose agricultural extension as a career path (Simpson et al. 2012).

Figure 24.3 compares proportions of women in farmer-trainer programs to their proportions in professional frontline extension positions in the same organizations. These organizations included NGOs, government agencies, producer organizations and private companies. If the proportion of women among farmer-trainers is higher than the proportion among professional frontline extension staff, then farmer-trainer programs can be said to help increase the proportion of women providing extension services. Results on this issue are mixed.

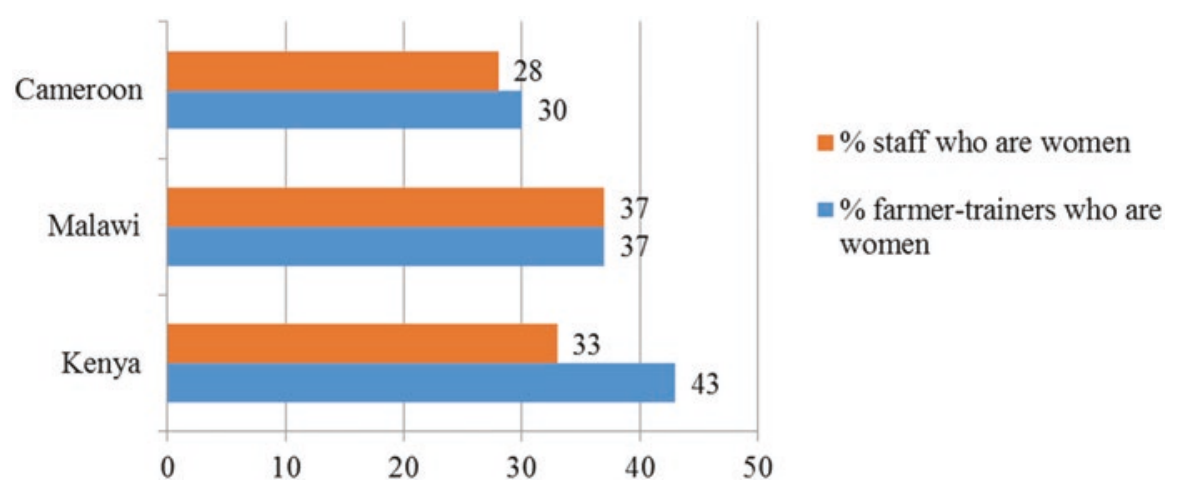

Fig. 24.3 Proportion of field staff and farmer-trainers who are women in organizations providing extension services. Note: Includes government, NGOs, private sector and farmer organizations 
In Kenya, the mean proportion of farmer-trainers who were women across the F2FE programs of 30 organizations was $43 \%$, while the mean proportion of field staff who were women in the same organizations was only $33 \%$. Thus the proportion of female extension providers among farmer-trainers was about 30\% higher than the proportion of women among field staff. In contrast, in Cameroon and Malawi, the mean proportion of farmer-trainers who were women was about the same as the mean proportion of field staff who were women (Fig. 24.3).

However, in certain organizations, the proportion of farmer-trainers who were women was dramatically higher than the proportion of female field staff. For example, in the East Africa Dairy Development Project in Kenya in 2013, only 10\% of the professional trainers were women, whereas $28 \%$ of the 1141 farmer-trainers were women. In the Ministry of Agriculture of Malawi in 2013, only 21\% of the field staff were women, whereas $40 \%$ of the 12,000 volunteer farmer-trainers were women. Organizations making special efforts to recruit female farmer-trainers, using such measures as targeting women's groups and providing childcare during training, were able to recruit high numbers of them. Nevertheless, low literacy levels among women limit the efforts being made to increase the number of women trainers because an ability to read and write is often a prerequisite for the position.

\subsection{Discussion}

These findings contribute to a growing body of knowledge on the effectiveness of farmer-trainers. Whereas no formal impact evaluations using randomized controlled trials were found, there have been several studies using quasi-experimental techniques or surveys of participants' perceptions and trainees' knowledge. Nakano et al. (2015) found that farmer-trainers in Tanzania were successful in disseminating knowledge about rice cultivation, and that the improved practices diffused to other farmers as well over a 5-year period. Wellard et al. (2013) found that farmers working with farmer-trainers in Ghana, Malawi and Uganda in collaboration with an NGO (Self-Help Africa) had significantly higher adoption rates than farmers in a control group. Lukuyu et al. (2012) found that volunteer farmer-trainers in Kenya were highly prized by their trainees and were still actively training their peers several years after project support had ended.

Only Wellard et al. (2013) examined the costs of farmer-trainers. They did not examine costs per farmer trained but did estimate overall benefit-cost ratios, based on increased adoption, yields and income in areas with farmer-trainers compared to controlled areas. Benefit-cost ratios ranged from 6.8:1 to 14.2:1, indicating that the investment in an F2FE program yields high returns. Concerning gender, no study was found that examined the role that F2FE could play in reducing gender imbalances in extension.

It is important to note that neither the above studies nor our own surveys dealt exclusively with CSA practices. One question, therefore, is whether findings concerning F2FE's performance in promoting a wide range of agricultural practices are 
also relevant for promoting CSA practices. An examination of a list of CSA practices, such as that provided by Harvey et al. (2014), reveals that it is not possible to generalize: CSA practices vary considerably in complexity; in whether new skills are required to apply them; and in the cost, resource intensity and length of time necessary to generate benefits (CIAT, BFS/USAID 2016). Given this complexity, perhaps a more relevant question is this: Are there types of practices that are not suitable to be promoted by farmer-to-farmer extension, and might these include some CSA practices? Franzel et al. (2015) reported that F2FE, though effective for a wide range of innovations, is less appropriate for complex practices (e.g., conservation agriculture), high-risk innovations where the cost of an error may be high (e.g., agrichemicals or artificial insemination) and for what are essentially permanent decisions (e.g., water retention ponds and dams). Degrande and Benoudji (2017) noted the need for close supervision of farmer-trainers by extension staff in a conservation agriculture initiative in Chad.

Franzel et al. (2015) also reported that F2FE may not perform well in certain situations, regardless of the type of practice promoted. For example, it does not do well in areas of low population density where transportation is a constraint, unless means of transport are provided. Performance may also be compromised in areas where farmers are not well organized. It also appears to be less suited to highincome commercial systems, where the opportunity cost of labor is high and social networks may be weak. It works best where farmer-trainers are serving members of a farmer group or a producer organization, because in these circumstances trainers already have a ready clientele.

\subsection{Implications for Development}

Among those using it, F2FE is perceived to be an effective approach for promoting a wide variety of practices-including CSA-under a wide range of circumstances. Scaling up of extension is essential for helping farmers adapt to climate change, and F2FE has great potential for helping in these efforts. The findings presented in this paper show that adding F2FE programs can help extension services increase the numbers of farmers they reach and promote uptake of CSA practices. F2FE, however, is not appropriate for all agricultural practices or situations. Moreover, whereas extension programs often find it difficult to recruit female professionals, some are able to significantly increase their proportion of female farmer-trainers by making special efforts to do so.

There are two other caveats to using the approach. First, F2FE can never be used to compensate for a poorly performing extension service. Farmer-trainers rely on extension staff for backstopping and education. As a result, if the extension staff are inadequately trained or lack transportation, farmer-trainers will not be effective. Second, neither F2FE nor any single extension approach on its own can scale up CSA to millions of farmers. Rather, F2FE needs to be combined with other comple- 
mentary approaches such as extension campaigns, farmer field schools or information and communication technology (ICT) approaches.

Finally, more research is needed on whether F2FE is effective for promoting CSA. For example, it would be useful to compare F2FE with more conventional extension approaches (e.g., extension staff working directly with farmer groups) in their ability to cope with changes in weather (e.g., rising temperatures over time) and increased weather risks (e.g., a rising probability of drought). Such research questions are extremely difficult and expensive to answer as they would require randomized controlled trials in which researchers compare the adoption of CSA technologies in villages that have farmer-trainers with those that do not. Villages with farmer-trainers would have to be located at considerable distance from those without in order to prevent "leakage" of the training information from one village to the other. Such research studies would likely require large samples (several thousand farmers) to ensure statistically valid findings and would take several years to conduct. Both quantitative and qualitative assessments would be needed.

But certain proxy questions for assessing the relevance of F2FE to CSA could be answered more easily, such as whether farmers prefer-and are more willing- to discuss their farming risks and risk responses with farmer-trainers rather than with extension agents. One could also test whether farmer-trainers are more skilled at recognizing the weather risks characterizing their agro-ecologies compared to extension agents, who are often less likely to have extensive experience in the particular region. Given that so many extension services already use F2FE, it would also be useful to assess more generic questions about how to improve its effectiveness, such as how to choose farmer-trainers, how to train and motivate them, and how to ensure the sustainability of the program.

\section{References}

CIAT, BFS/USAID (2016) Climate-smart agriculture in Senegal. CSA country profiles for Africa series. International Center for Tropical Agriculture (CIAT), Bureau for Food Security, United States Agency for International Development (BFS/USAID), Washington, DC

Degrande A, Benoudji C (2017) L'Agriculture de conservation repensée: contextualiser l'innovation pour la résilience au Tchad et au Soudan. BRACED Innovation for resilience case studies

Franzel S, Degrande A, Kiptot E, et al (2015) Farmer-to-farmer extension. Global forum for rural advisory services good practice notes for extension and advisory services, no. 7. Global Forum for Rural Advisory Services, Lindau, Switzerland

Franzel S, Sinja J, Simpson B (2014) Farmer-to-farmer extension in Kenya: the perspectives of organizations using the approach. ICRAF Working Paper no. 181. World Agroforestry Centre, Nairoibi. http://www.worldagroforestry.org/downloads/publications/PDFs/WP14380.PDF

GFRAS (2014) Gender equality in rural advisory services. Global Forum for Rural Advisory Services (GFRAS) brief no. 2. Global Forum for Rural Advisory Services, Lindau, Switzerland

Goodman LA (1961) Snowball sampling. Ann Math Stat 32:148-170 
Harvey CA, Chacón M, Donatti CI et al (2014) Climate-smart landscapes: opportunities and challenges for integrating adaptation and mitigation in tropical agriculture. Conserv Lett 7:77-90. https://doi.org/10.1111/conl.12066

Karanja E, Kiptot E, Franzel S (2017) The volunteer farmer-trainer approach three years after the exit of the East Africa Dairy Development Project: a case study of four dairy producer organizations in Kenya. ICRAF, Nairobi http://www.worldagroforestry.org/output/ volunteer-farmer-trainer-approach-three-years-after-exit-east-africa-dairy-development

Khaila S, Tchuwa F, Franzel S et al (2015) The farmer-to-farmer extension approach in Malawi: a survey of lead farmers, ICRAF Working Paper no. 189. World Agroforestry Centre, Nairobi http://www.worldagroforestry.org/downloads/publications/PDFs/ WP14200.PDF

Kiptot E, Franzel S (2012) Effectiveness of the farmer-trainers approach in dissemination of livestock feed technologies: a survey of volunteer farmer-trainers in Kenya. East African Dairy Development Project, Nairobi https://cgspace.cgiar.org/bitstream/handle/10568/34449/ Effectiveness \%20 of\%20farmer\%20trainer\%20approach\%20in\%20disseminating $\% 20$ feed $\% 20$ technologies.pdf?sequence $=1$

Kiptot E, Franzel S, Karanja E et al (2013) Effectiveness of the volunteer farmer-trainer approach in dissemination of livestock feed technologies: a survey of farmer trainees in Kenya. East African Dairy Development Project, Nairobi

Kiptot E, Franzel S, Nzigamasabo P et al (2016) Farmer-to-farmer extension of livestock feed technologies in Rwanda: a survey of volunteer farmer-trainers and organizations, ICRAF working paper no. 221. World Agroforestry Centre, Nairobi. https://doi.org/10.5716/ WP16005.PDF

Kundhlande G, Franzel S, Simpson B et al (2014) Farmer-to-farmer extension approach in Malawi: a survey of organizations, ICRAF working paper no. 183. World Agroforestry Centre, Nairobi http://www.worldagroforestry.org/downloads/publications/pdfs/WP14391.PDF

Lipper L, Thornton B, Campbell M et al (2014) Climate-smart agriculture for food security. Nat Clim Chang 4:1068-1107

Lukuyu B, Place F, Franzel S et al (2012) Disseminating improved practices: are volunteer farmertrainers effective? J Agric Educ Ext 18(5):525-554

Masangano C, Mthinda C (2012) Pluralistic extension system in Malawi, IFPRI discussion paper no. 01171. IFPRI, Washington, DC

McCarthy N, Lipper L, Branca G (2011) Climate-smart agriculture: smallholder adoption and implications for climate change adaptation and mitigation. FAO, Rome

Nakano Y, Tsusaka TW, Aida T et al (2015) The impact of training on technology adoption and productivity of rice farming in Tanzania: is farmer-to-farmer extension effective? JICA-RI working paper no. 90. JICA Research Institute, Tokyo

Scarborough V, Killough S, Johnson DA et al (eds) (1997) Farmer-led extension: concepts and practices. Intermediate Technology Publications, London

Selener D, Chenier J, Zelaya R (1997) Farmer-to-farmer extension: lessons from the field. International Institute for Rural Reconstruction, New York

Simpson B, Franzel S, Degrande A et al (2015) Farmer-to-farmer extension: issues in planning and implementation, MEAS technical note. USAID Modernizing Extension and Advisory Services, Washington, DC http://agrilinks.org/sites/default/files/resource/files/MEAS\%20 TN\%20Farmer\%20to\%20Farmer\%20-\%20Simpson\%20et\%20al\%20-\%20May\%202015. pdf

Simpson BM, Heinrich G, Malindi G (2012) Strengthening pluralistic agricultural extension in Malawi. MEAS rapid scoping mission. USAID Modernizing Extension and Advisory Services, University of Illinois, Urbana

Tsafack S, Degrande A, Franzel S et al (2014) Farmer-to-farmer extension in Cameroon: a survey of extension organizations, ICRAF working paper no. 182. World Agroforestry Centre, Nairobi http://www.worldagroforestry.org/downloads/publications/PDFs/WP14383.PDF 
Tsafack S, Degrande A, Franzel S et al (2015) Farmer-to-farmer extension: a survey of lead farmers in Cameroon, ICRAF working paper no. 195. World Agroforestry Centre, Nairobi http:// www.worldagroforestry.org/downloads/Publications/PDFS/WP15009.pdf

Wellard K, Rafanomezana J, Nyirenda M et al (2013) A review of community extension approaches to innovation for improved livelihoods in Ghana, Uganda and Malawi. J Agric Educ Ext 19(1):21-35

World Bank, Food and Agricultural Organization of the United Nations, International Fund for Agricultural Development (WB, FAO, IFAD) (2009) Gender in agriculture sourcebook. World Bank, Washington, DC

Open Access This chapter is licensed under the terms of the Creative Commons Attribution 4.0 International License (http://creativecommons.org/licenses/by/4.0/), which permits use, sharing, adaptation, distribution and reproduction in any medium or format, as long as you give appropriate credit to the original author(s) and the source, provide a link to the Creative Commons license and indicate if changes were made.

The images or other third party material in this chapter are included in the chapter's Creative Commons license, unless indicated otherwise in a credit line to the material. If material is not included in the chapter's Creative Commons license and your intended use is not permitted by statutory regulation or exceeds the permitted use, you will need to obtain permission directly from the copyright holder.

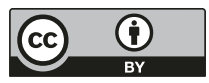

